\title{
İlkokul ve Ortaokul Öğretmenlerinin Mesleki Tükenmişlik ve Bazı Demografik Özelliklerinin Aile Katılımı Öz-yeterliklerini Yordama Düzeylerinin İncelenmesi
}

\section{Songül Tümkaya ${ }^{1}$}

\author{
Gürkan Çetin²
}

Type/Tür:

Research/Araştırma

Received/Geliş Tarihi: March 3/

3 Mart 2020

Accepted/Kabul Tarihi: June 23/

23 Haziran 2020

Page numbers/Sayfa No: 139-158

Corresponding

Author/İletişimden Sorumlu

Yazar: gurkancetin92@gmail.com

\section{$\checkmark$ iThenticate $^{\circ}$}

This paper was checked for plagiarism using iThenticate during the preview process and before publication. / Bu çalışma ön inceleme sürecinde ve yayımlanmadan önce iThenticate yazılımı ile taranmıştır.

Copyright $(2017$ by Cumhuriyet University, Faculty of Education. All rights reserved.

\begin{abstract}
Öz
$\mathrm{Bu}$ araştırmada, ilkokul ve ortaokullarda görev yapan öğretmenlerin mesleki tükenmişlik ve aile katılımı özyeterliklerinin ne düzeyde olduğunu ve öğretmenlerin mesleki tükenmişlik düzeylerinin ve bazı demografik özelliklerinin aile katılımı öz-yeterliklerini ne düzeyde yordadığının belirlenmesi amaçlanmıştır. Betimsel çalışma niteliğinde ilişkisel tarama modeli ile yapılan bir çalışmadır. Araştırmada 191'i ilkokul, 187 'si ortaokul olmak üzere 378 öğretmen yer almıştır. Verilerin toplanmasında kişisel bilgi formu, aile katılımına ilişkin öz-yeterlik ölçeği ve Maslach mesleki tükenmişlik ölçeği kullanılmıştır. Elde edilen verilerin analizinde betimsel istatistikler, çoklu regresyon analizi öncesi gerekli olan, değişkenlerin arasındaki ilişkiyi ve bu ilişkinin yönlerini belirmek için Pearson korelasyon analizi ve çok değişkenli doğrusal regresyon analizleri yapılmıştır. Araştırmanın sonuçlarına göre öğretmenlerin aile katılımı öz-yeterlikleri düşük düzeyde bulunmuştur. Mesleki tükenmişlik düzeyleri ise duygusal tükenmişlik alt boyutuna göre az tükenmiş, duyarsızlaşma alt boyutuna göre çok az tükenmiş ve kişisel başarısızlık alt boyutuna göre ise orta düzeyde tükenmiş şeklindedir. Yapılan ilk çoklu regresyon analizi sonucuna göre yordayıcı değişkenlerden kıdem, çalıştı̆̆ı okul türü, seminerkurs alma durumu ve kitap okuma durumunun, aile katılımı öz-yeterlik üzerinde anlamlı yordayıcılar olduğu bulunmuştur. Diğer çoklu regresyon analizi sonucuna göre ise mesleki tükenmişlik alt boyutlarından kişisel başarısızlık alt boyutu aile katılımı öz-yeterliklerinin anlamlı bir yordayıcı olurken, duyarsızlaşma ve duygusal tükenmişlik alt boyutlarını ise anlamlı bir yordayıcı olmadığı sonucuna ulaşılmıştır.
\end{abstract}

Anahtar Kelimeler: Mesleki tükenmişlik, aile katılımı özyeterlik, öğretmenler, ilkokul, ortaokul

\section{Suggested APA Citation/Önerilen APA Atıf Biçimi:}

Tümkaya, S., \& Çetin, G. (2021). İlkokul ve ortaokul öğretmenlerinin mesleki tükenmişlik ve bazı demografik özelliklerinin aile katılımı öz-yeterliklerini yordama düzeylerinin incelenmesi. Cumhuriyet International Journal of Education, 10(1), 139-158. http://dx.doi.org/10.30703/cije.697637

\footnotetext{
1 Prof. Dr., Çukurova Üniversitesi, Eğitim Fakültesi, Temel Eğitim Bölümü, Adana/Türkiye Prof. Dr., Çukurova University, Faculty of Education, Department of Primary Teaching, Adana/Turkey e-mail: stumkaya@cu.edu.tr ORCID ID: orcid.org/0000-0003-0140-4640

2 Arş. Gör., Harran Üniversitesi, Eğitim Fakültesi, Temel Eğitim Bölümü, Şanlıurfa/Türkiye Res. Assist., Harran University, Faculty of Education, Department of Primary Teaching, Sanliurfa/Turkey e-mail: gurkancetin92@gmail.com ORCID ID: orcid.org/0000-0002-5535-0097
} 


\title{
Investigating The Prediction Levels of Primary School and Secondary School Teachers' Professional Burnout and Some Demographic Features of Family Participation Self-Efficacy
}

\begin{abstract}
In this study, it was aimed to determine the level of professional burnout and family participation self-efficacy of teachers working in primary and secondary schools, and to what extent teachers' professional burnout levels and some demographic characteristics predicted family participation self-efficacy. This research is a descriptive study that has the relational screening model. There were 378 participating teachers in total in the present study, 191 from primary schools and 187 from secondary schools. Personal data form, self-efficacy scale and Maslach professional burnout scale related to family participation were used in data collection. In the analysis of the data obtained, descriptive statistics, Pearson correlation analysis and multivariate linear regression analysis were performed to determine the relationship between the variables and the directions of this relationship, which are required before the multiple regression analysis. According to the results of the study, teachers' family participation self-efficacy was found to be low. Occupational burnout levels are slightly depleted according to the emotional burnout sub-dimension, slightly depleted according to the depersonalization sub-dimension and moderately exhausted according to the personal failure subdimension. According to the results of the first multiple regression analysis, seniority, school type, seminar-course taking status and book reading status were found to be significant predictors of family participation self-efficacy. According to the results of the other multiple regression analysis, it was concluded that the family participation selfefficacy of the personal failure sub-dimension, which is one of the professional burnout sub-dimensions, is a significant predictor, while the depersonalization and emotional burnout sub-dimensions are not significant predictors.
\end{abstract}

Keywords: Professional burnout, family participation self-efficacy, teachers, primary school, secondary school.

\section{Giriş}

Günümüzde çocukların eğitim süreçlerinden sadece okul ve öğretmenlerin sorumlu olduğu düşüncesi artık değişmekle birlikte bu düşüncenin yerini çocuğun eğitim sürecinden okul ve öğretmenler kadar ailenin de önemli derecede sorumlu olduğu düşüncesi almıştır. Öğrencinin başarılı olması için ailelerinde eğitim sürecine etkin bir şekilde katılım sağlaması çok önemlidir. Ailelerin bu şekilde eğitime katılımının sağlanması, eğitimin niteliğini de önemli katkılarda bulunur (Lindberg ve Demircan, 2013). Çünkü bireyin doğduktan sonra ilk iletişim kurduğu sosyal birim ailedir. Bu yüzden aile, çocuğun hayatının her alanında çok önemli bir yer tutar (Dönmez ve Ramazan, 2017). Çocuk bu ailenin bir üyesi olduğu için ve aynı zamanda ailenin etkilendiği herhangi bir durumdan çocukta etkilendiği için eğitimciler olarak eğer çocuğu başarıya ulaştırma ve çocuğa yatırım yapma düşüncemiz varsa kesinlikle çocuğu ailesinden bağımsız olarak düşünemeyiz (Keilty, 2010; akt. Dönmez ve Ramazan, 2017). Aile katılımı en basit tanımıyla aslında ailenin eğitim süreçlerine etkin bir şekilde katılmasıdır. Bireyin eğitim sürecinin ve gelişim düzeyinin en iyi seviyeye ulaşması için öğretmen, okul ve aile arasında oluşturulan bir işbirliğidir (Arabacı, 2014). Dönmez ve Ramazan (2017) ise aile katılımını; ailenin desteklenmesi, ailenin etkin bir biçimde eğitim sürecine dâhil olması, aile-okul-öğretmen arasındaki iletişim düzeyinin ve iletişim sıklı̆ının artması ve bu durumların bireyin öğrenmesini destekleyici bir yaklaşım haline gelmesi olarak tanımlamaktadır. Şahin ve Ünver 
(2005)'e göre aile katılımı; ailelerin hem programlara katılım sürecinde hem de çocuklarına karşı faydalı olacak yeteneklerini ortaya çıkarma sürecidir.

Aile katılımı, okul-öğretmen-aile arasında ilişki kurmayı ve aralarında gerekli olan bilgi akışını sağlar. Öğretmenlerin aile katılımına yönelik programlar oluşturup ailelere çocukları hakkında bilgiler vermesi ve aileler ile fikir alışverişi yapması ve aileleri sürece dahil etmesi sayesinde ailelerde eğitim sürecine sorumluluk olarak katıldıklarında ne kadar değer verildiklerini görürler. Ayrıca bir süre sonra ailelerde sorumluluk alıp eğitim sürecinde aktif rol aldıklarında birçok konuda da öğretmene yardımcı olacak duruma gelebilirler (Yakıcı, 2018). Ailelerin eğitim sürecine dâhil olması; okula ve öğretmene olan güveninin artması, ailenin çocuklarla birlikte etkinliklere katılmaktan zevk alması ve çocuğun ne kadar öğrenme gereksinimi duyduğunu anlaması, çocuğun her türlü gelişiminden haberdar olması, bazı etkinlikler sayesinde ailenin bazı becerilerini ortaya çıkarma ve çocuğun evde öğrenme ortamının bilinçli şekil hazırlanması gibi faydaları da beraberinde getirir (Atakan, 2010).

Aile katılımının bu gibi faydalarından yararlanılmasını engelleyen bazı faktörlerde bulunmaktadır. Moles (1993; akt. Ahioğlu Linberg, 2014)'e göre aile katılımı etkileyen üç ana faktör vardır. Bunlardan birincisi, işbirliğini etkileyen annebaba-öğretmen kaynaklı kültürel ve psikolojik faktörlerdir. Bu grupta yer alan ailelerin farklı dil konuştukları için iletişim kuramamaktan ve kültürel farklılıklarından dolayı öğretmenler tarafından eleştirilme korkusudur. Öğretmenlere baktığımızda ise onlarda ailelerle iletişim kurmaktan çekindikleri için bu durum aile katılımını engeller. Diğer bir faktör ise aile ile öğretmenlerin etkileşim durumlarının yetersiz olmasıdır. Özellikle hem anne hem babanın çalışma hayatında olduğu, çalışma saatlerinin uyumsuzluğu aynı şekilde öğretmeninde aşırı iş yükü ve yerine getirmesi gereken diğer sorumluluklarından dolayı aile katılım süreci sekteye uğramaktadır. Aile katılımını etkileyen en önemli faktörde öğretmenlerin aile katılımına yönelik yetersiz bilgi ve beceriye sahip olmalarıdır. Bu durumda öğretmenlerin lisans eğitiminde aile katılımı ile ilgili yeterli ders almaması ya da öğretmen olduktan sonra aile katılımına yönelik bir hizmet içi eğitim fırsatı bulamaması veya böyle bir fırsat olduğu halde bunu değerlendirmemesi anlamlarına gelebilir.

Aile katılımı modellerini incelediğimizde ise alanyazında en çok kabul gören model Epstein (2010)'ın “çakışan küreler" kavramıyla açıkladı̆̆ı aile katılım modelidir. Bu modelde Epstein (2010) altı farklı şekilde aile katılım türünden bahsetmektedir. Bunlar:

1. Anne-babalık (Parenting): Anne ve babanın bir öğrenci olarak çocuğun başarısını desteklemek için uygun ev ortamı yaratması konusunda aileleri bilgilendirme.

2. İletişim (Communicating): Okul programları ve çocukların gelişimi hakkında okuldan-eve ve evden-okul iletişim sağlamak için etkili formlar tasarlamak ve aile ile iletişim kurmak.

3. Gönüllülük (Volunteering): Ailelerin okulun ihtiyacı olan kaynakları yaratmasına ek olarak okul içinde gerçekleştirilecek uygulamalara gönüllü bir şekilde katılımlarını sağlayabilecek uygulamalar. 
4.Evde öğrenme (Learning at home): Öğrencilerin ödevleri ve müfredatla ilişkili aktiviteler, kararlar ve planlama gibi diğer sorumlulukları ile ilgili nasıl yardım edecekleri konusunda ailelere gerekli bilgiler sağlamak.

5.Karar verme (Decision making): Okulun tüm eğitim sürecinde ailelerin karar verme aşamalarına dâhil edilmesi.

6.Toplumla işbirliği (Collaborating with community): Toplumun, öğrencilerin gelişimini desteklemesi amacıyla aile ve öğrencilerle ilgili kaynak ve hizmetler konusunda bilgilendirilmesi.

Öğretmenler bu aile katılım süreçlerinde en kritik faktördür. Öğretmenin aile katılımını önemseyip önemsememesi, ailelerle işbirliği içinde çalışıp çalışmaması ve aile katılımı ile ilgili destekleyici nitelikte programlar oluşturup oluşturamaması aile katılım sürecini oldukça fazla etkiler (Kaya, 2007). Bu gibi çalışmaları yapabilmesi için ise öğretmenin öz yeterliğinin iyi durumda olması gerekir. Öz yeterlik; insanın karşılaştığ 1 durumlarla baş edebilmek için kendi yetenek ve birikimine olan inanc1 olarak tanımlanabilir (Senemoğlu, 2007). Bir alanda öz yeterliği yüksek düzeyde olan bireyler, o alana yönelik daha fazla istekli bir çaba içine girerler (Schunk, 2014). Öğretmenlerin günümüzdeki gelişmeleri güncel bir şekilde takip edebilmeleri ve kendilerini yaşanan değişimlere uyarlamaları öz yeterlik ile çok yakından ilişkilidir. Öz yeterlik algısı bireylerin yaşam içindeki hedeflerini ve bu hedeflere ulaşma yolunda göstereceği gayreti etkiler (Özata, 2007).

Öğretmenlerin aile katılım süreçlerini etkileyen önemli değişkenlerden biri de mesleki tükenmişliktir. Günümüzde tükenmişlik durumu birçok meslek alanları açısından ciddi bir problemdir. Özellikle de insanlarla iletişimin ve etkileşimin sık olduğu meslek dallarında bu sorunun görünme olasılığı daha fazladır (Maslach, Schaufe ve Leither, 2001; Oplatka, 2002). Öğretmenlik mesleği de insanlarla sürekli etkileşim içinde olunan bir meslek olduğu için öğretmenlikte bu sorunun görünme olasılığı daha fazla olabilir. Mesleki tükenmişlik; insanlara yardım ve hizmet gerektiren mesleklerde çalışan kişilerin duygusal tükenmişlik, duyarsızlaşma ve kişisel başarı duygusunun azalması şeklinde oluşan bir sendrom olarak tanımlanır (Maslach ve Jackson, 1981).

Mesleki tükenmişliğin nedenlerini incelediğimizde yaş, cinsiyet, medeni durum ve eğitim durumu gibi kişisel nedenler ve işte çalışma süresi, aşırı iş fazla iş yükü, çalışma arkadaşlarıyla ilişkiler ve çalışılan ortamın özellikleri gibi örgütsel nedenler olarak iki boyuttur (Akman, 2019). Çalışanların kendilerini fazla zorlaması, insanın kendisine katı kurallar koyması, mükemmeliyetçi bir yapıya sahip olma ve işte beklenmedik zamandaki yükselişte tükenmişliğe neden olabilir (Murat, 2000). Tükenmişlik durumu, insanlarla sürekli iletişim halinde olunan meslek dallarında çok fazla görülmekle beraber, öğretmenlik mesleği ise tükenmişliği en yaygin görüldüğü meslek dalları arasında olduğu için yapılan çalışmaların büyük bir kısmı öğretmenler ile ilgilidir (Tümkaya ve Çavuşoğlu, 2010).

Maslach, Schaufe ve Leither (2001) tükenmişlik kavramını duygusal tükenmişlik, duyarsızlaşma ve kişisel başarı olarak üç boyut olarak ele almışlardır. Duygusal tükenme boyutu tükenmişliğin bireysel stres yönünü ele almakta ve insanın fiziksel ve duygusal kaynaklarında meydana gelen azalmayı göstermektedir. Duygusal tükenmişlik yaşayan insanlar yeni bir iş günü endişesi ile uyanırlar. Bireyler 
bu duygusal yorgunluk halinden kurtulabilmek için diğer çalışanlarla iletişimlerini en az düzeye indirmeye veya tamamen iletişimi kesmeye çabalarlar (Akman, 2019). Duyarsızlaşma boyutu ise tükenmişlik kavramının bireyler arası boyutunu göstermekte ve işte müşterilere yönelik katı davranışları ve işe karşı tepkisiz hale gelmeyi ifade eder. Bireyler çalışma ortamlarında meydana gelen olumsuz olaylar karşısında tepkisiz hale gelirler ve etkileşimde oldukları bireyleri bir obje gibi görürler (Akman, 2019). Kişisel başarı duygusu boyutu ise bireyin kendini negatif değerlendirme anlayışı halinde olması durumudur. Bu boyutta insan, iş yerindeki çoğalan taleplere yetişemediğini ve mesleki yeterlik seviyesinde de bir azalma geldiğini fark ederler. Kişi burada işinden uzaklaşabilir (Akman, 2019).

Aile katılım ile ilgili (Arabacı ve Aksoy, 2005; Akkök Ögetürk, Kökdemir, 1997; Akkök Ögetürk, Kökdemir, Annak (2000); Canyaşar, 2001; Castro, Bryant, PeisnerFeinberg, Skinner, 2004; Coleman ve Churchill, 1997; Cömert ve Güleç, 2005; Croizer, 1999; Dearing, Kreider, Simpkins, Weiss, 2006; Çamlıbel Çakmak, 2010; Erdoğan ve Demirkasımoğlu, 2010; Eğmez, 2008; Ersoy, 2003; Fantuzzove Perry, 2004; Gürşimşek, 2003; Hornby, 2000; Huntsinger ve Jose, 2009; Izzo, Weissberg, Kasprow ve Fendrich, 1999; İşman ve Yıldız, 1996; Kaya, 2002; Kaya, Changir ve Din, 2004; Knopf ve Swick, 2008; Laloumi, 1997; McBride ve Rain, 2001; McCarrik vd., 2007; Ömeroğlu ve Canyaşar, 2005; Ömeroğlu, Yazıcı ve Dere, 2003; Pehlivan, 2000; Pelletier ve Brent, 2002; Rimm-Kaufman, Pianta, Cox, Bradley, 2003; Unutkan, 1998; Ural, 2005; Ünüvar, 2010; Waanders, Mendez ve Downer, 2005; Yazar, Çelik ve Kök, 2008; Yazıcı, Yüksel ve Güzeller, 2005, Zembat ve Unutkan, 1999)(Akt. Selanik Ay ve Aydoğdu, 2016) tarafından ve Atakan (2010), Ekinci Vural (2012), Oğuz (2012), Lindberg ve Demircan (2013), Ahioğlu Lindberg (2014), Argon ve Kıyıcı (2012), Şad ve Gürbüztürk (2013), Ateş (2015), Ahioğlu Lindberg ve Oğuz (2016), Bayraktar, Güven ve Temel (2016), Selanik Ay ve Aydoğdu (2016), Aydoğdu ve Kılıç (2016), Dönmez ve Ramazan (2017), Yakıcı (2018) tarafından yapılan çalışmaların büyük çoğunluğu okul öncesinde aile katılımı ile ilgili olduğu görülmektedir. Literatürde ilkokul ve ortaokul öğretmenlerinin aile katılımına yönelik bir yordama çalışmasına ve mesleki tükenmişlik ile ilişkilendirilmiş bir çalışmaya rastlanılmamıştır. Bu sebeple böyle bir çalışmanın literatüre katkı sağlayacağı düşüncesi ile bu çalışmanın yapılması gerekliliği duyulmuştur. Araştırmada ilkokul ve ortaokul öğretmenlerinin mesleki tükenmişlik ve aile katılımı öz-yeterliklerinin ne düzeyde olduğunun tespit edilmesi de hedeflenmekle beraber aslında temelde mesleki tükenmişlik ve bazı demografik özelliklerin, öğretmenlerin aile katılımına yönelik öz-yeterliklerini ne düzeyde yordadığının tespit edilmesi amaçlanmaktadır. Bu amaçlara yönelik araştırma soruları şunlardır:

1. İlkokul ve ortaokul öğretmenlerinin aile katılımı öz-yeterlikleri hangi düzeydedir?

2. İlkokul ve ortaokul öğretmenlerinin mesleki tükenmişlikleri hangi düzeydedir?

3. İlkokul ve ortaokul öğretmenlerinin bazı demografik özellikleri aile katılımı öz-yeterliklerini ne düzeyde yordamaktadır?

4. İlkokul ve ortaokul öğretmenlerinin mesleki tükenmişlikleri aile katılımı öz-yeterliklerini ne düzeyde yordamaktadır? 


\section{Yöntem}

\section{Araştırmanın Modeli}

İlkokul ve ortaokul öğretmenlerinin mesleki tükenmişlik düzeyleri ve bazı demografik özelliklerinin, aile katılımına yönelik öz-yeterliklerini yordama düzeylerinin incelenmesini araştırmayı amaçlayan bu çalışma, ilişkisel tarama modelinin kullanıldı ̆̆ı betimsel nitelikte bir çalışmadır. Tarama araştırmaları, diğer araştırma modelleriyle karşılaştırıldığında daha büyük sayıda örneklem ile yapılan, bir olay veya olguyla ilgili araştırmaya katılan kişilerin tutum, görüş, beceri gibi sahip oldukları özellikleri tespit etmeyi amaçlayan araştırmalardır (Büyüköztürk, Kılıç Çakmak, Akgün, Karadeniz ve Demirel, 2014). İlişkisel tarama modelindeki araştırmalar ise iki veya ikiden fazla değişkenin kendi aralarındaki birlikte değişimini veya değişimin ne düzeyde olduğunu belirlemeye çalışan araştırmalardır (Karasar, 2016).

\section{Evren ve Örneklem}

Bu çalışmanın evrenini 2018-19 eğitim-öğretim yılında Türkiye'nin güneydoğusunda yer alan bir ilde görev yapan ilkokul ve ortaokul öğretmenleri oluştururken, araştırmanın örneklemini ise bu ilde görev yapan 191 ilkokul ve 187 ortaokul öğretmeni oluşturmaktadır. Araştırmanın örneklemi oluşturulurken, araştırmacı için kolay ulaşılabilirlik ve elverişlilik imkânı sağlayan "uygun örnekleme" yöntemi tercih edilmiştir. Uygun örnekleme; zaman, para, ve iş gücü kaybının önlenmesini hedefleyen bir yöntemdir (Büyüköztürk vd., 2014). Örnekleme ilişkin bilgilere Tablo 1 'de yer verilmiştir:

Tablo 1'de görüldüğü gibi araştırmaya 192'si (\% 50.8) kadın, 186'sı (\% 49.2) erkek olmak üzere 378 kişi katılmıştır. Bu kişilerin 146'sı (\% 38.6) bekar, 232'si (\% 61.4) evlidir. Öğretmenlerin 231'i (\% 61.1) 0-5 yıl, 53’ü (\% 14.0) 6-10 yıl, 33’ü (\% 8.7) 11-15 yıl, 25'i (\% 6.6) 16-20 yıl, 19'u (\% 5.0) 21-25 yıl ve 17'si (\% 4.5) ise 25 yıl ve üzeri kıdeme sahiptir. Katılımcıların 84'ü (\% 22.2) 22-26 yaş, 122'si (\% 32.3) 27-31 yaş, 48'i (\% 12.7) 32-36 yaş, 63'ü (\%16.7) 37-41 yaş, 27'si (\% 7.1) $42-46$ yaş aralığında ve 34'ü (\% 9.0) ise 46 yaş üzeridir. Öğretmenlerin 288'i (\% 76.2) eğitim fakültesi, 90'1 (\%23.8) ise diğer fakülte mezunlarıdır. Öğretmenlerin 191'i (\%50.5) ilkokulda çalışıyorken, 187'si (\% 49.5) ise ortaokulda çalışmaktadır. Katılımcıların 328' i (\% 86.8) öğretmenliği isteyerek seçmişken, 50'si (\% 13.2) öğretmenliği isteyerek seçmediğini, 109'u (\% 28.8) daha önce aile katılımı ile ilgili ders aldığını, 269’u (\% 71.2) daha önce aile katılımı ile ilgili ders almadığını, 103'ü (\% 27.2) daha önce aile katılımı ile ilgili kurs, seminer vb. faaliyete katıldığını, 275'i (\% 72.8) daha önce aile katılımı ile ilgili kurs, seminer vb. faaliyete katılmadığını, 265'i (\% 70.1) daha önce aile katılımı ile ilgili kitap okuduğunu, 113'ü ise (\% 29.9) daha önce aile katılımı ile ilgili kitap okumadığını belirtmektedir. 
Tablo 1

Örneklemin Demografik Özelliklerine Göre Dağılımı

\begin{tabular}{|c|c|c|}
\hline & $\mathbf{N}$ & $\%$ \\
\hline \multicolumn{3}{|l|}{ Cinsiyet } \\
\hline Kadın & 192 & 50.8 \\
\hline Erkek & 186 & 49.2 \\
\hline \multicolumn{3}{|l|}{ Medeni Durum } \\
\hline Bekar & 146 & 38.6 \\
\hline Evli & 232 & 61.4 \\
\hline \multicolumn{3}{|l|}{ K1dem } \\
\hline $0-5 Y_{11}$ & 231 & 61.1 \\
\hline 6-10 Y1l & 53 & 14.0 \\
\hline 11-15 Y1l & 33 & 8.7 \\
\hline $16-20 Y_{11}$ & 25 & 6.6 \\
\hline 21-25 Y1l & 19 & 5.0 \\
\hline 25 Yıl üzeri & 17 & 4.5 \\
\hline \multicolumn{3}{|l|}{ Yaş } \\
\hline $22-26$ & 84 & 22.2 \\
\hline $27-31$ & 122 & 32.3 \\
\hline $32-36$ & 48 & 12.7 \\
\hline $37-41$ & 63 & 16.7 \\
\hline $42-46$ & 27 & 7.1 \\
\hline 46 yaş üzeri & 34 & 9.0 \\
\hline \multicolumn{3}{|c|}{ Mezun Olunan Fakülte } \\
\hline Eğitim Fakültesi & 288 & 76.2 \\
\hline Diğer & 90 & 23.8 \\
\hline \multicolumn{3}{|c|}{ Çalıştığ́ Okul Türü } \\
\hline İlkokul & 191 & 50.5 \\
\hline Ortaokul & 187 & 49.5 \\
\hline \multicolumn{3}{|c|}{ Öğretmenliği İsteyerek Seçme Durumu } \\
\hline Evet & 328 & 86.8 \\
\hline Hayır & 50 & 13.2 \\
\hline \multicolumn{3}{|c|}{ Aile Katılımı İle İlgili Ders Alma Durumu } \\
\hline Evet & 109 & 28.8 \\
\hline Hayır & 269 & 71.2 \\
\hline \multicolumn{3}{|c|}{ Aile Katılımı İle İlgili Kurs, Seminer vb. Katılma Durumu } \\
\hline Evet & 103 & 27.2 \\
\hline Hayır & 275 & 72.8 \\
\hline \multicolumn{3}{|c|}{ Aile Katılımı İle İlgili Kitap Okuma Durumu } \\
\hline Evet & 265 & 70.1 \\
\hline Hayır & 113 & 29.9 \\
\hline Toplam & 378 & 100 \\
\hline
\end{tabular}

\section{Veri Toplama Araçları}

1.Kişisel bilgi formu. Kişisel bilgi formu, ilkokul ve ortaokul öğretmenlerinin meslekteki kıdem, cinsiyet, yaş, medeni durum, mezun oldukları fakülte, görev yaptığ1 okul tipi, öğretmenlik mesleğini isteyerek seçip seçmediği, lisans düzeyinde aile katılımına yönelik bir ders alıp almadığı, aile katılımı ile ilgili akademik faaliyetlere (seminer, kurs vb.) katılıp katılmadığı ve aile katılımı ile ilgili bir kitap okuyup okumadığı gibi bilgilere ulaşmak için araştırmacı tarafından hazırlanmıştır. 
2. Aile katılıma ilişkin öz-yeterlik ölçeği. Bu çalışmada ilkokul ve ortaokul öğretmenlerinin aile katılımı öz-yeterliklerini belirlemek için Ateş (2015) tarafından geliştirilmiş olan “Aile Katılımına Yönelik Öz-yeterlik" adlı ölçek uygulanmıştır. Likert tipi yedili derecelendirmeli (1:Çok az yeterli hissediyorum, 7:Çok yeterli hissediyorum) şeklindeki ölçek toplam 21 maddeden oluşmaktadır. Ateş (2015), ölçek için yapmış olduğu güvenirlik analizi sonucunda güvenirlik katsayısını (Cronbach Alpha) 948 olarak hesaplamıştır. Bu sonuca göre de ölçeğin yüksek düzeyde güvenilir olduğu söylenebilir. Yapılan bu çalışmada ise güvenirlik analizi ilkokul ve ortaokul öğretmenlerinden elde edilen puanlar ile yapılmış ve güvenirlik katsayısı (Cronbach Alpha) .90 olarak bulunmuştur. Ölçeğin kapsam ve görünüş geçerliği için ise iki uzmandan görüş alınmıştır.

3. Maslach mesleki tükenmişlik ölçeği. İlkokul ve ortaokul öğretmenlerinin mesleki tükenmişliklerini belirlemek için Maslach ve Jackson (1981) tarafından geliştirilen 7'li likert tipi ölçek, Ergin (1992) tarafından Türkçeye 5'li likert tipi olarak uyarlanmıştır. Tükenmişlik ölçeği, duygusal tükenmişlik, duyarsızlaşma ve kişisel başarı olmak üzere üç boyuttan ve 22 maddeden oluşmaktadır. "Duygusal tükenmişlik" boyutu 9 maddeden (1.,2.,3.,6.,8.,13.,14.,16.,20.maddeler), "duyarsızlaşma boyutu" 5 maddeden (5.,10.,11.,15.,22.maddeler) ve "kişisel başarı" boyutu ise 8 maddeden (4.,7.,9.,12.,17.,18.,19.,21.maddeler) oluşmaktadır. Likert tipi beşli derecelendirmeli ölçek 1:Kesinlikle Katılmıyorum, 2:Katılmıyorum, 3:Kararsızım, 4:Katılıyorum, 5:Kesinlikle Katılıyorum) biçimindedir. Kişisel başarı boyutunda yer alan maddeler ise ters puanlama yapılmıştır. Bundan dolayı da bu boyut "kişisel başarısızlık" olarak kullanılmıştır. Ergin (1992), tükenmişlik ölçeği için yaptığ1 güvenirlik analizinde güvenirlik katsayısını (Cronbach Alpha) duygusal tükenmişlik için .83, duyarsızlaşma boyutu için .65 ve kişisel başarısızlık boyutu için ise .72 olarak hesaplamıştır.

Bu çalışmada ise güvenirlik analizi ilkokul ve ortaokul öğretmenlerinden elde edilen puanlar ile yapılmış ve güvenirlik katsayısı (Cronbach Alpha) duygusal tükenmişlik için .90, duyarsızlaşma boyutu için .75 ve kişisel başarısızlık boyutu için ise .70 olarak bulunmuştur. Ölçeğin kapsam ve görünüş geçerliği için ise iki uzmandan görüş alınmıştır.

\section{Verilerin Analizi}

Araştırma kapsamında toplanan veriler SPSS 22.0 paket programina girilerek oluşturulan veri dosyası üzerinde betimsel istatistikler ve çoklu regresyon analizleri yapılmıştır. Öncelikle ilkokul ve ortaokul öğretmenlerinin aile katılımı öz-yeterlik ve mesleki tükenmişlik düzeylerini belirleme amacıyla betimsel istatistiklerden yararlanılmış ve ortalama ile standart sapma değerleri bulunmuştur. Bu aşamadan sonra çoklu regresyon analizleri yapabilmek amacıyla gerekli varsayımları test etmek için araştırmada yer alan değişkenlerin arasındaki ilişkiyi ve bu ilişkinin yönlerini belirlemek için Pearson Korelasyon Analizi yapılmıştır. Pearson korelasyon analizi sonucunda kıdem ile yaş arasında çok doğrusallık sorunu bulunduğundan yaş değişkeni analize dahil edilmemiştir. Daha sonra ise bir başka varsayım olan normallik analizi ve hataların normalliği analizleri yapılmış ve her ikisinin de normal dağılım sergilediği görülmüştür. Çoklu regresyon analizi kısmında ilkokul ve ortaokul öğretmenlerinin demografik değişkenleri (cinsiyet, mezun oldukları fakülte, medeni 
durum, meslekteki kıdem, , görev yaptığı okul tipi, öğretmenlik mesleğini isteyerek seçip seçmediği, lisans düzeyinde aile katılımına yönelik bir ders alıp almadığı, aile katılımı ile ilgili akademik faaliyetlere (seminer, kurs vb.) katılıp katılmadı̆̆ı ve aile katılımı ile ilgili bir kitap okuyup okumadığı) ile mesleki tükenmişliğin alt boyutlarını oluşturan duygusal tükenmişlik, duyarsızlaşma ve kişisel başarısızlık değişkenleri araştırmanın bağımsız değişkenleri olarak belirlenirken, aile katılım öz-yeterlikleri ise bağımlı değişken olarak belirlenmiştir. İkinci ve üçüncü alt problemlere ilişkin yapılan çoklu regresyon analizinde varsayımlardan biri olan bağımsız değişkenler arasında çoklu doğrusallık olmaması varsayımı tüm bağımsız değişkenlerde Varyans Büyütme Faktörü $(\mathrm{VIF})<10$ ve Tolerans Değeri $>0,2$ olduğu için çoklu doğrusallık varsayımı sağlanmıştır. Çoklu regresyon analizi, “bir bağımlı (yordanan) değişken ile bununla ilişkisi olan bir dizi yordayıcı değişken arasındaki ilişkiyi ortaya koymak için yapılan bir analizdir" (Can, 2016, s.273).

\section{Bulgular}

Araştırma sonunda elde edilen bulgular araştırma sorularına göre; öğretmenlerin aile katılımı öz-yeterlik düzeylerine ilişkin bulgular, öğretmenlerin mesleki tükenmişlik düzeylerine ilişkin bulgular, pearson korelasyon analizi bulguları, aile katılımı özyeterliklerini yordayıcı bazı demografik değişkenlere ilişkin çoklu regresyon analizi bulguları ve aile katılımı öz-yeterliklerini yordayıcı mesleki tükenmişlik alt boyutları değişkenlerine ilişkin çoklu regresyon analizi bulguları şeklinde verilmiştir.

\section{Öğretmenlerin Aile Katılımı Öz-Yeterlik Düzeylerine İlişkin Bulgular}

Öğretmenlerin aile katılımı öz-yeterlik düzeylerine ilişkin bulgular Tablo 2'de verilmiştir.

Tablo 2

Aile Katılımı Öz-Yeterliklerine İlişkin Ortalama ve Standart Sapma Değerleri

\begin{tabular}{lcc}
\hline Ölçek & Ortalama & Standart Sapma \\
\hline Aile Katılımı Öz-Yeterlikleri & 3.83 & 1.11 \\
\hline
\end{tabular}

Öğretmenlerin aile katılım öz-yeterlik düzeyleri ile ilgili verilerin analizi sonrasında elde edilen bulgular Tablo 2'de gösterilmiştir. Tablo 2 incelendiğinde öğretmenlerin aile katılım öz yeterlikleri yedili bir likert tipi ölçek olmasına karşın Ateş (2015, s.82)' in “Öz-Yeterlik Puan Aralığına” göre düşük düzeyde olduğu söylenebilir ( $\square: 3.83$ ). Öğretmenlerin aile katılım öz-yeterlik puanlarının standart sapma değeri ise $(\mathrm{Sx}=1.11)$ bulunmuştur.

\section{Öğretmenlerin Mesleki Tükenmişlik Düzeylerine İlişkin Bulgular}

Öğretmenlerin mesleki tükenmişlik düzeylerine ilişkin bulgular Tablo 3’te verilmiştir. Öğretmenlerin mesleki tükenmişlik alt boyutları olan, duygusal tükenmişlik, duyarsızlaşma ve kişisel başarısızlık düzeyleri ile ilgili verilerin analizi sonrasında elde edilen bulgular Tablo 3’de gösterilmiştir. Beşli likert tipi şeklinde olan mesleki tükenmişlik ölçeğinde, Kılınç (2018, s.31)'ın “Mesleki Tükenmişlik Puan Aralığına” göre değerlendirdiğimizde 9 maddeye karşılık gelen duygusal tükenmişlik boyutu az tükenmiş ( $\square: 2.20)$, 5 maddeye karşılık gelen duyarsızlaşma boyutu çok az tükenmiş 
( $\square: 1.77)$ ve 8 maddeye karşılık gelen kişisel başarısızlık boyutu ise orta düzeyde tükenmiş ( $\square: 3.35)$ şeklinde yorumlanabilir. Öğretmenlerin en yüksek ortalamaya sahip olduğu boyut kişisel başarısızlık boyutu iken en düşük ortalamaya sahip olduğu boyut ise duyarsızlaşma boyutudur.

Tablo 3

Mesleki Tükenmişliğin Alt Boyutlarna İlişkin Ortalama ve Standart Sapma Değerleri

\begin{tabular}{lcc}
\hline Ölçek Alt Boyutları & Ortalama & Standart Sapma \\
\hline Duygusal Tükenmişlik & 2.20 & 0.80 \\
\hline Duyarsızlaşma & 1.77 & 0.69 \\
\hline Kişisel Başarısızlık & 3.35 & 0.38 \\
\hline
\end{tabular}

\section{Pearson Korelasyon Analizi Bulguları}

Tablo 4.

Mesleki Tükenmişliğin Alt Boyutları, Aile Katılımı Öz-Yeterlikleri ve Demografik Değişkenler Arasindaki Korelasyon Değerleri

\begin{tabular}{|c|c|c|c|c|c|c|c|c|c|c|c|c|c|c|}
\hline Değişkenler & $\mathrm{C}$ & $\mathbf{M}$ & $\mathbf{K}$ & $\mathbf{Y}$ & $\mathbf{F}$ & $\mathrm{O}$ & Ö $\breve{g}$ & D & $S$ & Kİ & DT & DU & KİŞ & ÖZ \\
\hline Cinsiyet (C) & 1 & & & & & & & & & & & & & \\
\hline $\begin{array}{l}\text { Medeni Durum } \\
\text { (M) }\end{array}$ & $-.150^{* *}$ & 1 & & & & & & & & & & & & \\
\hline K1dem (K) & $-.310^{* *}$ & $.354^{* *}$ & 1 & & & & & & & & & & & \\
\hline Yaş (Y) & $-.333^{* *}$ & $.377^{* *}$ & $.914^{\star *}$ & 1 & & & & & & & & & & \\
\hline Fakülte (F) & .046 & .029 & $-.177^{* *}$ & $-.234^{\star *}$ & 1 & & & & & & & & & \\
\hline Okul Tipi (O) & $.190^{\star *}$ & -.046 & -.028 & -.093 & $.254^{\star *}$ & 1 & & & & & & & & \\
\hline $\begin{array}{l}\text { Öğretmenlik } \\
\text { Seçme (Öğ) }\end{array}$ & .084 & -.053 & -.072 & -.056 & .093 & .020 & 1 & & & & & & & \\
\hline Ders Alma (D) & $.136^{* *}$ & -.083 & -.081 & $-.154^{* *}$ & $.109^{*}$ & $.209^{* *}$ & .007 & 1 & & & & & & \\
\hline Seminer (S) & -.016 & .010 & $.214^{\star *}$ & $.132^{*}$ & -.090 & $.190^{* *}$ & -.007 & $.371^{* *}$ & 1 & & & & & \\
\hline $\begin{array}{l}\text { Kitap } \\
\text { (Kİ) }\end{array}$ & $.155^{\star *}$ & $.111^{*}$ & $.140^{* *}$ & .099 & -.012 & .013 & $.171^{* *}$ & $.212^{* *}$ & $.296^{\star *}$ & 1 & & & & \\
\hline $\begin{array}{l}\text { Duygusal } \\
\text { Tükenmişlik } \\
\text { (DT) }\end{array}$ & .031 & $.112^{*}$ & -.077 & $-.107^{*}$ & $.149^{* *}$ & .039 & $-.302^{* *}$ & .037 & .055 & -.069 & 1 & & & \\
\hline $\begin{array}{l}\text { Duyarsızlaşma } \\
\text { (DU) }\end{array}$ & -.020 & .043 & $-.191^{\star *}$ & $-.223^{* *}$ & $.128^{*}$ & .024 & -.085 & .039 & .079 & -.032 & $.585^{\star *}$ & 1 & & \\
\hline $\begin{array}{l}\text { Kişisel } \\
\text { Başarısızlık (Kİ) }\end{array}$ & $-.124^{* *}$ & .020 & $.285^{* *}$ & $.265^{* *}$ & $-182^{* *}$ & -.041 & .017 & .070 & $.196^{* *}$ & $.172^{\star *}$ & $-.449^{* *}$ & $-413^{* *}$ & 1 & \\
\hline $\begin{array}{l}\text { Öz-Yeterlik } \\
\text { (ÖZ) }\end{array}$ & $.059^{*}$ & $.048^{*}$ & $.192^{* *}$ & $.172^{\star *}$ & $-.062^{*}$ & $.185^{\star *}$ & $-.028^{*}$ & $.131^{*}$ & $.330^{* *}$ & $.270^{\star *}$ & $-.065^{*}$ & $-.030^{*}$ & $.285^{\star *}$ & 1 \\
\hline
\end{tabular}

Değişkenler arasındaki ilişkileri incelemek için yapılan Pearson Korelasyon analizi sonuçları Tablo 4'te verilmiştir. Buna göre aile katılım öz-yeterlik boyutu, kişisel başarısızlık boyutu ile pozitif doğrultuda düşük bir düzeyde anlamlı ilişki $(\mathrm{r}=.285, \mathrm{p}<0.01)$, duyarsılaşma boyutu ile negatif doğrultuda düşük bir düzeyde anlamlı ilişki $(\mathrm{r}=-.030, \mathrm{p}<0.05)$, duygusal tükenmişlik boyutu ile negatif doğrultuda düşük bir düzeyde anlamlı ilişki (r=-.065, p<0.05), aile katılımına yönelik kitap okuma 
ile pozitif doğrultuda düşük bir düzeyde anlamlı ilişki $(\mathrm{r}=.270, \mathrm{p}<0.01)$, aile katılımına yönelik seminere katılma ile pozitif doğrultuda orta derecede anlamlı bir ilişki ( $\mathrm{r}=.330$, $\mathrm{p}<0.01$ ), aile katılımına yönelik ders alma ile pozitif doğrultuda düşük derecede anlamlı ilişki $(\mathrm{r}=.131, \mathrm{p}<0.05)$, öğretmenliği seçme durumu ile negatif doğrultuda düşük bir düzeyde anlamlı ilişki ( $\mathrm{r}=-0.028, \mathrm{p}<0.05)$, çalışılan okul tipi ile pozitif doğrultuda düşük bir düzeyde anlamlı ilişki ( $\mathrm{r}=.185, \mathrm{p}<0.01)$, mezun oldukları fakülte ile negatif doğrultuda düşük bir düzeyde anlamlı ilişki (r=-.062, p<0.05), yaş ile pozitif doğrultuda düşük bir düzeyde anlamlı ilişki $(\mathrm{r}=.172, \mathrm{p}<0.01$, kıdem ile pozitif doğrultuda düşük bir düzeyde anlamlı ilişki ( $\mathrm{r}=.192, \mathrm{p}<0.01)$, medeni durum ile pozitif doğrultuda düşük bir düzeyde anlamlı ilişki $(r=.048, p<0.05)$, cinsiyet ile pozitif doğrultuda düşük bir düzeyde anlamlı bir ilişki $(r=.059, p<0.05)$ olduğu görülmektedir.

Kişisel başarısızlık boyutu, duyarsızlaşma boyutu ile negatif doğrultuda orta derecede ilişkiye $(\mathrm{r}=-.413, \mathrm{p}<0.01)$, duygusal tükenmişlik boyutu ile negatif doğrultuda orta düzeyde ilişkiye $(\mathrm{r}=-.449, \mathrm{p}<0.01)$ sahiptir. Duyarsızlaşma boyutu ile duygusal tükenmişlik boyutu arasında ise pozitif doğrultuda orta derecede anlamlı bir ilişki $(r=.585, \mathrm{p}<0.01)$ vardır.

Demografik değişkenlerin kendi aralarındaki ilişkilere baktığımızda ise yaş ile kıdem arasında yüksek düzeyde bir ilişki olduğundan (.80 ve üzeri)(Büyüköztürk, 2005, s.100) ve bu durumunda çok doğrusallık sorunu ortaya çktığından yaş değişkeni çoklu regresyon analizine dahil edilmemiştir.

\section{Aile Katılımı Öz-Yeterliklerini Yordayıcı Bazı Demografik Değişkenlere İlişkin Çoklu Regresyon Analizi Bulguları}

Öğretmenlerin aile katılımı öz-yeterliklerini yordayıcı bazı demografik değişkenlere ilişkin çoklu regresyon analizi bulguları Tablo 5'te verilmiştir.

Tablo 5

Aile Katılımı Öz-Yeterliklerini Yordayıcı Değişskenlere (Demografik Özellikler) İlişkin Çoklu Regresyon Analizi

\begin{tabular}{|c|c|c|c|c|c|}
\hline Yordayıcı Değişkenler & $B$ & SH & $\beta$ & $t$ & $p$ \\
\hline Sabit & 3.259 & 0.205 & - & 15.906 & .00 \\
\hline Cinsiyet & 0.113 & 0.116 & 0.051 & 0.980 & .32 \\
\hline Medeni Durum & -0.019 & 0.117 & -0.008 & -0.165 & .86 \\
\hline Kidem & 0.019 & 0.008 & 0.128 & 2.292 & $.02^{*}$ \\
\hline Mezuniyet (Fakülte) & -0.134 & 0.132 & -0.051 & -1.016 & .31 \\
\hline Çalıştığı Okul Türü & 0.336 & 0.114 & 0.152 & 2.941 & $.00^{* *}$ \\
\hline Öğretmenliği Seçme & -0.174 & 0.159 & -0.053 & -1.098 & .27 \\
\hline Ders Alma Durumu & -0.032 & 0.130 & -0.013 & -0.250 & .80 \\
\hline Seminer, Kurs Alma & 0.545 & 0.137 & 0.219 & 3,967 & $.00^{* *}$ \\
\hline Kitap Okuma Durumu & 0.460 & 0.127 & 0.190 & 3.621 & $.00^{* *}$ \\
\hline$N=378$ & $R=0.42$ & $R^{2}=0.18$ & & & \\
\hline$F_{(9,368)}=9.066$ & $p=.00$ & ${ }^{*} \mathrm{p}<0.05$ & $* * p<0.001$ & & \\
\hline
\end{tabular}

Aile katılımı öz-yeterlik üzerinde etkisi olduğu düşünülen, cinsiyet, medeni durum, kıdem, mezun olunan fakülte, çalıştığı okul türü, öğretmenliği isteyerek seçip seçmeme durumu, aile katılımı ile ilgili daha önce ders alıp almama durumu, aile katılımı ile ilgili daha önce seminer, kursa vb. katılıp katılmama durumu ve aile 
katılımı ile ilgili kitap okuyup okumama durumu gibi değişkenlerin, aile katılımı özyeterliklerini ne şekilde yordadığını ortaya koymaya yönelik olarak yapılan çoklu regresyon analizi sonucunda, yukarıda belirtilen değişkenler birlikte, aile katılım özyeterlikleri ile anlamlı bir ilişki $\left(R=0.42, R^{2}=0.18\right)$ sergilemişlerdir $\left(F_{(9,368)}=9.066\right.$, $\mathrm{p}<0.001)$. Söz konusu değişkenler birlikte, aile katılımı öz-yeterliklerindeki değişimin $\%$ 18'ini açıklamaktadır. Standartlaştırılmış regresyon katsayılarına göre, yordayıcı değişkenlerin, aile katılımı öz-yeterlikleri üzerindeki göreli önem sırası; seminer-kurs alma durumu ( $\beta: 0.219)$, kitap okuma durumu ( $\beta: 0.190)$, çalıştığ okul türü ( $\beta: 0.152)$, kıdem ( $\beta: 0.128)$, öğretmenliği seçme durumu ( $\beta:-0.053)$, mezun olunan fakülte ( $\beta$ :$0.051)$, cinsiyet ( $\beta: 0.051)$, ders alma durumu ( $\beta:-0.013)$ ve medeni durum $(\beta:-0.008)$ şeklindedir. Regresyon katsayılarının anlamlılık testleri göz önüne alındığında, yordayıcı değişkenlerden sadece kıdem, çalıştığı okul türü, seminer-kurs alma durumu ve kitap okuma durumunun, aile katılım öz-yeterlik üzerinde anlamlı yordayıcılar olduğu görülmektedir.

\section{Aile Katılımı Öz-Yeterliklerini Yordayıcı Mesleki Tükenmişlik Alt Boyutları Değişkenlerine İlişkin Çoklu Regresyon Analizi Bulguları}

Öğretmenlerin aile katılımı öz-yeterliklerini yordayıcı mesleki tükenmişlik alt boyutları değişkenlerine ilişkin çoklu regresyon analizi bulguları Tablo 6'da verilmiştir.

Tablo 6

Aile Katılımı Öz-Yeterliklerini Yordayıcı Değişkenlere (Mesleki Tükenmişlik Alt Boyutları) İlişkin Çoklu Regresyon Analizi

\begin{tabular}{lccccc}
\hline Yordayııı Değişkenler & $\boldsymbol{B}$ & $\boldsymbol{S H}$ & $\boldsymbol{\beta}$ & $\boldsymbol{t}$ & $\boldsymbol{p}$ \\
\hline Sabit & 0.251 & 0.653 & - & 0.384 & .70 \\
\hline Duygusal Tükenmişlik & 0.048 & 0.087 & 0.035 & 0.548 & .58 \\
\hline Duyarsılaşma & 0.142 & 0.100 & 0.089 & 1.425 & .15 \\
\hline Kişisel Başarısızlık & 0.960 & 0.161 & 0.337 & 5.976 & $.00^{* *}$ \\
\hline$N=378$ & $R=0.30$ & $R^{2}=0.09$ & & & \\
$F_{(3,374)}=12.494$ & $p=.00$ & ${ }^{*} \mathrm{p}<0.05$ & $* * \mathrm{p}<0.001$ & & \\
\hline
\end{tabular}

Aile katılımı öz-yeterlik üzerinde etkisi olduğu düşünülen, mesleki tükenmişlik alt boyutlarından olan duygusal tükenmişlik, duyarsızlaşma ve kişisel başarısızlık gibi değişkenlerin, aile katılımı öz-yeterliklerini ne şekilde yordadığını ortaya koymaya yönelik olarak yapılan çoklu regresyon analizi sonucunda, yukarıda belirtilen değişkenler birlikte, aile katılım öz-yeterlikleri ile anlamlı bir ilişki $\left(R=0.30, R^{2}=0.09\right)$ sergilemişlerdir $\left(F_{(3,374)}=12.494, \mathrm{p}<0.001\right)$. Söz konusu değiş̧kenler birlikte, aile katılımı öz-yeterliklerindeki değişimin \% 9'unu açıklamaktadır. Standartlaştırılmış regresyon katsayılarına göre, yordayıcı değişkenlerin, aile katılımı öz-yeterlikleri üzerindeki göreli önem sırası; kişisel başarısızlık ( $\beta: 0.337)$, duyarsızlaşma ( $\beta: 0.089)$ ve duygusal tükenmişlik ( $\beta: 0.087)$ şeklindedir. Regresyon katsayılarının anlamlılık testleri göz önüne alındığında, yordayıcı değişkenlerden sadece kişisel başarısızlık boyutunun, aile katılım öz-yeterlik üzerinde anlamlı bir yordayıcı olduğu görülmektedir. 


\section{Tartışma, Sonuç ve Öneriler}

Araştırmanın birinci araştırma sorusu "İlkokul ve ortaokul öğretmenlerinin aile katılımı öz-yeterlikleri hangi düzeydedir?" şeklindedir. Bu araştırma sorusunun bulgularına göre ilkokul ve ortaokul öğretmenlerinin aile katılım öz-yeterliklerinin düşük düzeyde olduğu bulunmuştur. Yakıcı (2018) velilerle yaptığı çalışmada, Akkaya (2007) ve Selanik Ay ve Aydoğdu (2016) öğretmenler ile yaptıkları çalışmada, Ateş (2015) öğretmen adaylarıyla yaptıkları çalışmada aile katılım öz-yeterliklerinin orta düzeyde olduğu sonucuna ulaşırken Ahioğlu Lindberg (2014), Gömleksiz ve Serhatoğlu (2013), Kaya (2007)ve Şenol (2012) yaptıkları çalışmalarda ise aile katılım öz-yeterliklerini yüksek düzeyde olduğu sonucuna ulaşmışlardır. Aile katılımı özyeterliği düşük olan öğretmenler, öğrencilerle ve velilerle iletişim konusunda sıkıntı yaşayabilirler. Aile katılım öz-yeterlikleri yüksek olan öğretmenler ise eğitim sürecinde aile katılımına çok daha fazla yer verirler. Öğretmenlerin aile katılım özyeterliklerinin genelde yüksek düzeyde olması olumlu bir sonuç olarak düşünülür. Bu çalışmada öğretmenlerin aile katılım öz-yeterliklerinin düşük düzeyde çıkması çalışılan bölge ve örneklemle ilgili olabilir. Çünkü çalışılan bölgedeki öğretmenlerin, dil, kültür, ailedeki çocuk sayısı vb. gibi nedenlerden dolayı velilerle aile katılımı konusunda sorun yaşama olasılığı fazladır. Bu durumda öğretmenlerin aile katılımı öz-yeterliklerinin düşük düzeyde çıkmasını etkilemiş olabilir.

Araştırmanın ikinci araştırma sorusu "İlkokul ve ortaokul öğretmenlerinin mesleki tükenmişlikleri hangi düzeydedir?" şeklindedir. Bu araştırma sorusunun bulgularına göre ilkokul ve ortaokul öğretmenlerinin duygusal tükenmişlik boyutunda "az tükenmiş", duyarsızlaşma boyutunda "çok az tükenmiş" ve kişisel başarısızlık boyutuna göre ise orta düzeyde tükenmiş oldukları bulunmuştur. Öğretmenlerin genel olarak duygusal tükenmişlik ve duyarsızlaşma boyutlarında düşük düzeyde tükenmiş olmaları, mesleki ilişkilerinin ve insanlarla iletişimlerinin iyi düzeyde olduğunu gösterebilir. Kişisel başarısızlık noktasında orta düzeyde bir tükenmişlik yaşadıkları göz önüne alındığında ilkokul ve ortaokul öğretmenlerinin meslekte kendilerini yeterince iyi düzeyde görmedikleri şeklinde yorumlanabilir. Kılınç (2018) öğretmenler ile yaptığ çalışmada öğretmenlerin mesleki tükenmişlik düzeylerini tüm alt boyutlarda "az tükenmiş" olarak bulmuştur. Teltik (2009) öğretmenler ile yaptığı çalışmada kişisel başarısızlık boyutunda düşük düzeyde, duygusal tükenmişlik ve duyarsızlaşma boyutlarında ise orta düzeyde tükenmişlik bulurken, Diri ve Kıral (2016) ortaokul öğretmenleri ile yaptığı çalışmada ise duygusal tükenmişlik boyutunu "orta düzeyde tükenmiş", duyarsızlaşma ve kişisel başarısızlık boyutlarını ise "az düzeyde tükenmiş" olarak bulmuştur. Çavuşoğlu (2005) ve YıldızToplu (2012)'nun öğretmenler ile yaptıkları çalışmalar incelendiğinde duygusal tükenmişlik, duyarsızlaşma ve kişisel başarısızlık boyutlarında az düzeyde tükenmişlik sonucuna ulaştıkları görülmektedir. Yıldız (2012) ise rehber öğretmenleri ile yaptığı çalışmada duygusal tükenmişlik ve duyarsızlaşma boyutlarını "az tükenmiş" olarak bulmuşken, kişisel başarısızlık boyutunu ise "çok fazla" tükenmiş olarak bulmuştur. Babaoğlan (006) ve Çatır (2014) okul yöneticileriyle yaptıkları çalışmalarda okul yöneticilerinin duygusal tükenmişlik, duyarsızlaşma ve kişisel başarısızlık boyutlarında "az tükenmiş" oldukları sonucuna ulaşmışlardır.

Araştırmanın üçüncü araştırma sorusu "İlkokul ve ortaokul öğretmenlerinin bazı demografik özellikleri aile katılımı öz-yeterliklerini ne düzeyde yordamaktadır?” 
şeklindedir. Cinsiyet, medeni durum, kıdem, mezun olunan fakülte, çalıştığı okul türü, öğretmenliği isteyerek seçip seçmeme durumu, aile katılımı ile ilgili daha önce ders alıp almama durumu, aile katılımı ile ilgili daha önce seminer, kursa vb. katılıp katılmama durumu ve aile katılımı ile ilgili kitap okuyup okumama durumu gibi değişkenlerin, aile katılımı öz-yeterliklerini yordayıp yormadığına baktığımız çoklu regresyon modelimizin anlamlı bir model olduğu sonucuna ulaşılmıştır. Bu değişkenler aile katılım öz-yeterliklerindeki değişimin \% 18'ini açıklamaktadır. Bu değişkenlerden sadece kıdem, çalışılan okul türü, seminer-kurs alma ve kitap okuma değişkenlerinin aile katılım öz-yeterliklerinin anlamlı bir yordayıcısı olduğu sonucunda ulaşılmıştır. Öğretmenin kıdem arttıkça aynı zamanda yaşadığı durumlar karşısında tecrübesi de artmış olacağı için aile katılımı konusunda etkili olmasının beklendik bir sonuç olduğu söylenebilir. Diğer taraftan Çalışılan okul türü değişkenine bakacak olursak ilkokul ve ortaokulda aile katılım süreçleri lise ve daha üst düzeylere göre daha fazla yaşandığı için bu değişkenin de aile katlımı üzerindeki etkisi olduğu söylenebilir. Ayrıca ilkokul öğretmenlerinin daha etkili olması ise lisans dönemlerinde aile katılımı ile ilgili daha fazla derslerinin olması ya da öğrenci yaş grubu olarak ailelerle çok daha fazla etkileşime girmelerinden kaynaklandığ söylenebilir. Daha önce aile katılımı ile ilgili herhangi bir seminer-kurs vb. etkinliklere katılma ve aile katılımı ile ilgili kitap okunması öğretmeni aile katılımı konusunda daha yeterli hale getirdiği için bu değişkenini aile katılımı üzerinde bir etkisi olduğu söylenebilir.

Araştırmanın dördüncü araştırma sorusu "İlkokul ve ortaokul öğretmenlerinin mesleki tükenmişlikleri aile katılımı öz-yeterliklerini ne düzeyde yordamaktadır?" şeklindedir. Mesleki tükenmişlik alt boyutlarından olan duygusal tükenmişlik, duyarsızlaşma ve kişisel başarısızlık gibi değişkenlerin, aile katılımı öz-yeterliklerini yordayıp yordamadığına baktığımız çoklu regresyon analizi sonucunda modelimizin anlamlı olduğu görülmektedir. Bu değişkenler aile katılım öz-yeterliklerinin \% 9 'unu açıklamaktadır. Duygusal tükenmişlik ve duyarsızlaşma boyutlarının aile katılım özyeterliklerini anlamlı şekilde yordamadığı, kişisel başarısızlık boyutunun ise aile katılım öz-yeterliklerini anlamlı bir şekilde yordadığı sonucuna ulaşılmıştır. Kişisel başarısızlık öğretmenlerin mesleki yeterlikleri ile ilişkili olduğundan, öğretmenlerin aile katılım öz-yeterliklerini etkilediği söylenebilir.

Araştırmada elde edilen bulgular neticesinde bazı öneriler sunulmuştur. Araştırmanın sonucuna göre öğretmenlerin aile katılımı öz-yeterlikleri düşük düzeyde çıkmıstır. Bu sebeple kurumlar, öğretmenleri aile katılımı konusunda hizmet içi eğitimlerle desktekleyip onları aile katılımı konusunda teşvik etmelidirler. Araştırmanın bir başka sonucuna göre öğretmenlerin, mesleki tükenmişliğin kişisel başarısızlık alt boyutunda orta düzeyde tükenmiş oldukları yani meslekte kendilerini iyi düzeyde göremedikleri sonucu ortaya çıkmıştır. Bu nedenle kurumlar, öğretmenlere mesleki eğitim düzeyinde hizmet içi destekler vermelidir. Bu araştırma sadece Güneydoğu Anadolu bölgesindeki bir ilde yapıldığı için başka illerde de uygulanıp sonuçlar karşılaştırılarak bir genelleme yapılabilir. Ayrıca aile katılımı özyeterliklerini yordayabileceği düşünülen başka değişkenlerde katılarak çalışma zenginleştirilebilir ve literatüre farklı bakış açıları kazandırılabilir. 


\section{Kaynakça}

Ahioğlu Lindberg, E. N. (2014). Eğitim fakültesi son sınıf öğrencilerinin aile katılımı ile ilgili görüşleri. Kuram ve Uygulamada Eğitim Bilimleri, 14(4), 1339-1361.

Ahioğlu Lindberg, E. N. ve Oğuz, K. (2016). İlköğretimde aile katılımı: Bir geçerlilik ve güvenirlilik çalışması. Journal of Human Sciences, 13(3), 4135-4151. https:// doi.org/10.14687/ijhs.v13i3.3711

Akkaya, M. (2007). Öğretmenlerin ve velilerin okul öncesi eğitim kurumlarında uygulanan aile katılımı çalışmalarına ilişkin görüşleri. (Yayımlanmamış Yüksek Lisans Tezi), Anadolu Üniversitesi Eğitim Bilimleri Enstitüsü.

Akman, T. (2019). Öğretmenlerin mesleki tükenmişlik düzeyleri ve mesleki doyumlarının incelenmesi. (Yayımlanmamış Yüksek Lisans Tezi), Marmara Üniversitesi-İstanbul Sabahattin Zaim Üniversitesi Ortak Program Sosyal Bilimler Enstitüsü.

Arabacı, N. (2014). Okul öncesi eğitimde aile katılımı (Bölüm 2). Her yönüyle okul öncesi eğitim 10 (ss. 305-327). Ankara: Hedef Yayıncılık.

Argon, T. ve Kıyıc1, C. (2012). İlköğretim kurumlarında ailelerin eğitim sürecine katılımlarına yönelik öğretmen görüşleri. Dicle Üniversitesi Ziya Gökalp Eğitim Fakültesi Dergisi, 19, 80-95.

Atakan, H. (2010). Okul öncesi eğitiminde aile katılımı çalışmalarının öğretmen ve ebeveyn görüşlerine göre değerlendirilmesi. (Yayımlanmamış Yüksek Lisans Tezi), Çanakkale Onsekiz Mart Üniversitesi Sosyal Bilimler Enstitüsü.

Ateş, Ö. (2015). Okul öncesi öğretmen adaylarının aile katılım çalışmalarına yönelik öz-yeterlik inançlarının incelenmesi. (Yayımlanmamış Yüksek Lisans Tezi), Pamukkale Üniversitesi Eğitim Bilimleri Enstitüsü.

Aydoğdu, F. ve Kılıç, D. (2016). Sınıf, okul öncesi ve özel eğitim öğretmenlerinin aile katılımına ilişkin tutumlarının incelenmesi. Erzincan Üniversitesi Sosyal Bilimler Enstitüsü Dergisi, 9 (1), 265-274. https:/ / doi.org/10.17218/hititsosbil.280813

Babaoğlan, E. (2006). İlköğretim okulu yöneticilerinde tükenmişlik. (Yayımlanmamış Doktora Tezi), Abant İzzet Baysal Üniversitesi Sosyal Bilimler Enstitüsü.

Bayraktar, V., Güven, G. ve Temel, Z. F. (2016). Okul öncesi kurumlarda görev yapan öğretmenlerin aile katılım çalışmalarına yönelik tutumlarının incelenmesi. Kastamonu Ĕ̈itim Dergisi, 24(2), 755-770.

Büyüköztürk, Ş. (2005). Sosyal bilimler için veri analizi el kitabı: İstatistik, araştırma deseni, SPSS uygulamaları ve yorum. Ankara: Pegem Akademi Yayıncılık.

Büyüköztürk, Ş., Kılıç Çakmak, E., Akgün, Ö. E., Karadeniz, Ş. ve Demirel, F. (2014). Bilimsel Araştırma Yöntemleri (18.bs.). Ankara: Pegem Akademi Yayıncılık.

Can, A. (2016). SPSS ile bilimsel araştırma süresince nicel veri analizi (4.bs.). Ankara: Pegem Akademi.

Çatır, V. (2014). İkili öğretim yapan ilköğretim kurumlarında (İlkokul-Ortaokul) görevli yöneticilerin mesleki tükenmişlik düzeyleri ile örgütsel bağlılıkları arasındaki ilişki. (Yayımlanmamış Yüksek Lisans Tezi), Yeditepe Üniversitesi Sosyal Bilimler Enstitüsü.

Çavuşoğlu, İ. (2005). Endüstri meslek liselerinde çalışan öğretmenlerin tükenmişlik düzeyleri ile bazı kişisel değişkenlerin arasındaki ilişki (Bolu İli Örneği).

(Yayımlanmamış Yüksek Lisans Tezi), Abant İzzet Baysal Üniversitesi Sosyal Bilimler Enstitüsü. 
Dönmez, Ö. ve Ramazan, O. (2017). Okul öncesi öğretmen adaylarının aile katılımına yönelik tutumları ile öz yeterlilik inançları arasındaki ilişkinin incelenmesi. Yıldız Sosyal Bilimler Enstitüsü Dergisi, 1(1), 29-45.

Diri, M. S. ve Kıral, E. (2016). Ortaokul öğretmenlerinin iş doyumlarının mesleki tükenmişlik düzeylerine etkisi. Mehmet Akif Ersoy Eğitim Fakültesi Dergisi, 39, 125-149. https:/ / doi.org/10.21764/efd.81587

Ekinci Vural, D. (2012). Okul öncesi eğitimin ilköğretime etkisinin aile katılım ve çeşitli değişkenler açısında incelenmesi. (Yayımlanmamış Doktora Tezi), Dokuz Eylül Üniversitesi Eğitim Bilimleri Enstitüsü.

Epstein, J. L. (2010). School/family/community partnerships: Caring for the children we share. Phi Delta Kappan, 92(3), 81-96. https:/ / doi.org/10.1177/003172171009200326

Ergin, C. (1992). Doktor ve hemşirelerde tükenmişlik ve Maslach tükenmişlik ölçeğin uyarlanması. VII. Ulusal Psikoloji Kongresi Bilimsel Çalışmaları El Kitabı,143154.

Gömleksiz, M. N. ve Serhatoğlu, B. (2013). Okul öncesi öğretmenlerinin öz-yeterlik inançlarına ilişkin görüşleri.Turkish Studies-International Periodical For The Languages, Literature and History of Turkish or Turkic, 8(7), 201-221. https:// doi.org/10.7827/TurkishStudies.5336

Karasar, N. (2016). Bilimsel araştırma yöntemi: kavramlar, ilkeler, teknikler. Ankara: Nobel Akademi Yayıncilık.

Kaya, R. (2007). The attitudes of preschool teachers toward parent involvement. (Yayımlanmamış Yüksek Lisans Tezi), Orta Doğu Teknik Üniversitesi Sosyal Bilimler Enstitüsü.

Kılınç, B. (2018). Fen bilimleri öğretmenlerinin mesleki tükenmişlik düzeylerinin bazı değişkenler açısından incelenmesi. (Yayımlanmamış Yüksek Lisans Tezi), Furat Üniversitesi Eğitim Bilimleri Enstitüsü.

Lindberg, E. N. ve Demircan, A. (2013). Ortaöğretim okullarında aile katılımının değerlendirilmesi: aile katılım ölçeği veli ve öğretmen formlarının Türkçeye uyarlanması. Cumhuriyet Uluslararası Eğitim Dergisi, 2(3), 64-78.

Maslach, C. and Jackson, S. (1981). The measurement of experienced burnout. Journal of Occupational Behaviour, (2), s.99-113. https:// doi.org/10.1002/job.4030020205

Maslach, C., Schaufeli, W. B., and Leither, M.P. (2001). Job burnout. Annual Review of Psychology, 52, 397-422. https:// doi.org/10.1146/annurev.psych.52.1.397

Murat, M. (2000). Sını öğretmenlerinde son 10 yıllık meslek sürecinde tükenmişliğin gelişiminin haritalanması ve bazı değişkenlere göre incelenmesi. (Yayımlanmamış Doktora Tezi), Karadeniz Teknik Üniversitesi Sosyal Bilimler Enstitüsü.

Oğuz, K. (2012). İlköğretim okullarında aile katılımı: ölçek uyarlaması. (Yayımlanmamış Yüksek Lisans Tezi), Kastamonu Üniversitesi Sosyal Bilimler Enstitüsü.

Oplatka, I. (2002). Women principals and the concept of burnout: An alternative voice? International Journal of Leadership in Education, 5(3), 211-226. https:/ / doi.org/10.1080/136031200112873

Özata, H. (2007). Öğretmenlerin öz-yeterlik algılarının ve örgütsel yenileşmeye ilişkin görüşlerinin araştırılması. (Yayımlanmamış Yüksek Lisans Tezi), Kocaeli Üniversitesi Sosyal Bilimler Enstitüsü. 
Schunk, D. H. (2014). Sosyal bilişsel teori (Bölüm 3) (Çev. M. Yasin). Learning Theories: An Educational Perspective (Öğrenme Teorileri: Ĕ̆gitimsel Bir Bakışla) (Çev. M. Y. Demir, K. Celasun, Z. H. Kaçkar, E. Üzümcü, \& B. E. Şahin; M. Şahin (Ed.)). Ankara: Nobel Akademik Yayıncılık.

Selanik Ay, T. ve Aydoğdu, B. (2016). Sınıf öğretmenlerinin aile katılımına yönelik görüşleri. Adıyaman Üniversitesi Sosyal Bilimler Enstitüsü Dergisi, 8(23), 562-590. https:/ / doi.org/10.14520/adyusbd.04626

Senemoğlu, N. (2007). Gelişim öğrenme ve öğretim. Ankara: Gönül Yayıncılık.

Şad, S. N. ve Gürbüztürk, O. (2013). İlköğretim birinci kademe öğrenci velilerinin çocuklarının eğitimine katılım düzeyleri. Kuram ve Uygulamada Ĕ̆̈itim Bilimleri Dergisi, 13(2), 993-1011.

Şahin, F. T. ve Ünver, N. (2005). Okul öncesi eğitim programlarına aile katılımı. Kastamonu Ĕ̈itim Dergisi, 13(1), 23-30.

Şenol, F. B. (2012). Okul öncesi öğretmen adaylarn ile okul öncesi öğretmenlerinin öğretmenlik mesleğine yönelik öz-yeterlik inançlarının karşılaştırılması. (Yayımlanmamış Yüksek Lisans Tezi), Afyon Kocatepe Üniversitesi Sosyal Bilimler Enstitüsü.

Teltik, H. (2009). Okul öncesi öğretmenlerinin mesleki yeterlilik algılarının iş doyumu ve tükenmişlik düzeyleriyle ilişkisinin belirlenmesi. Yayımlanmamış Yüksek Lisans Tezi, Marmara Üniversitesi Eğitim Bilimleri Enstitüsü.

Tümkaya, S. ve Çavuşoğlu, İ. (2010). Sınıf öğretmenliği son sınıf öğretmen adaylarının tükenmişlik düzeylerinin incelenmesi. Ç.Ü. Sosyal Bilimler Enstitüsü Dergisi, 19(2):468-481.

Yakıcı, A. P. (2018). Okul öncesi velilerinin aile katılımın yordayan değişkenlerin incelenmesi. (Yayımlanmamış Yüksek Lisans Tezi), Uşak Üniversitesi Sosyal Bilimler Enstitüsü.

Yılmaz-Toplu, N. (2012). Okul öncesi ve ilköğretim öğretmenlerinin tükenmişlik düzeyleri. (Yayımlanmamış Yüksek Lisans Tezi), Adnan Menderes Üniversitesi Sosyal Bilimler Enstitüsü.

\section{Summary}

\section{Introduction}

Today, the idea that only schools and teachers are responsible for the education process of children has changed, but this idea has been replaced by the idea that the family is as much responsible for the education process of the child as the school and teachers. Ensuring the participation of families in education in this way also contributes significantly to the quality of education and student success (Lindberg \& Demircan, 2013). Family participation, in its simplest definition, is the active involvement of the family in educational processes. It is a collaboration between teacher, school and family in order to reach the best level of education process and development level of the individual (Arabac1, 2014).

One of the important variables that affect teachers' family participation processes may be professional burnout. Today burnout is a serious problem for many professions. This problem is more likely to appear especially in the fields of communication and interaction with people (Maslach, Schaufe \& Leither, 2001; Oplatka, 2002). Maslach, Schaufe and Leither (2001) discussed the concept of burnout 
in three dimensions as emotional burnout, depersonalization and personal success. The emotional exhaustion dimension addresses the individual stress aspect of burnout and shows the reduction in the physical and emotional resources of man. In order to get rid of this emotional fatigue, individuals try to minimize their communication with other employees or cut the communication completely (Akman, 2019). The depersonalization dimension shows the inter-individual dimension of the concept of burnout and refers to the strict behavior towards customers and to become unresponsive to work. Individuals become unresponsive in the face of negative events occurring in their working environment and see the individuals they interact with as an object (Akman, 2019). The personal sense of success dimension is when the individual has a negative self-evaluation approach. In this dimension, people realize that they cannot meet the increasing demands in the workplace and there is a decrease in the level of professional competence. In the research, it is aimed to determine the level of professional burnout and family participation self-efficacy of primary and secondary school teachers. In fact, it is aimed to determine the level of professional burnout and some demographic characteristics that predict teachers' self-efficacy towards family participation. Research questions for these purposes are:

1. What is the level of family participation self-efficacy of primary and secondary school teachers?

2. What is the level of professional burnout of primary and secondary school teachers?

3. To what extent do some demographic characteristics of primary and secondary school teachers predict family participation self-efficacy?

4. To what extent do the professional burnout of primary and secondary school teachers predict family participation self-efficacy?

\section{Method}

This study, which aims to investigate the levels of professional burnout and some demographic features, and the levels of predicting self-efficacy towards family participation, is a descriptive study using the relational screening model. The population of the study consist of primary and middle school teachers who are recruited in a city of the south eastern region of Turkey. The sample involves totally 191 primary school teachers and 187 middle school teachers. In data collection, personal information form, "Self-efficacy towards Family Participation" scale developed by Ateş (2015) and "Maslach Occupational Burnout Scale" 7-point-likert type developed by Maslach ve Jackson (1981) and 5-point-likert type adapted in Turkish by Ergin (1992) was adapted to be used. Descriptive statistics (mean, standard deviation) pearson correlation analysis and multiple regression analysis were used to analyze the data.

\section{Findings}

It can be said that teachers' family participation self-efficacy is low according to the "Self-Efficacy Score Range" ( $\square: 3.83$ ). The emotional burnout dimension of teachers can be interpreted as depleted $(\square: 2.20)$, depersonalization dimension as depleted ( $\square$ : 1.77), and personal failure dimension as exhausted ( $\square$ : 3.35). Considering the significance tests of the regression coefficients, it is seen that the predictive variables are only predictors of family participation self-efficacy. Considering the significance 
tests of regression coefficients, it is seen that only the personal failure dimension, which is one of the predictive variables, is a significant predictor of family participation self-efficacy.

\section{Result and Discussion}

In this study, low family participation self-efficacy of teachers may be related to the region and sample studied. Since families have diverse backgrounds regarding languages, culture, or number of children in the family, teachers may face problems with families regarding family participation. For reasons such as parents are more likely to have problems with family participation. In this case, teachers' family involvement may have affected the low self-efficacy. The low level of teachers' exhaustion in terms of emotional burnout and depersonalization may indicate that their professional relationships and communication with people are good. Considering that they experience a moderate burnout at the point of personal failure, it can be interpreted that primary and secondary school teachers do not see themselves well enough in the profession. It can be said that it is an expected result that the teacher will be effective in family participation, as the experience will increase as the seniority increases as well as the experience one has. On the other hand, if we look at the variable of the type of school studied, it can be said that this variable has an effect on family participation as the family participation processes in primary and secondary schools are higher than the high school and at higher levels. It was concluded that emotional burnout and depersonalization dimensions did not significantly predict family participation self-efficacy, while personal failure dimension significantly predicted family participation self-efficacy. Since personal failure is related to teachers' professional competencies, it can be said that they affect the family participation selfefficacy of teachers.

\section{Pedagogical Implications}

As a result of the findings obtained in the research, some suggestions are presented. Since this research was conducted only in a province located in the Southeastern Anatolia region, the results can be compared again in other regions. The study can be enriched by involving other variables that are thought to predict family participation self-efficacy.

\section{Araştırmanın Etik Taahhüt Metni}

Yapılan bu çalışmada bilimsel, etik ve alıntı kurallarına uyulduğu; toplanan veriler üzerinde herhangi bir tahrifatın yapılmadığı, karşılaşılacak tüm etik ihlallerde "Cumhuriyet Uluslararası Eğitim Dergisi ve Editörünün" hiçbir sorumluluğunun olmadığı, tüm sorumluluğun Sorumlu Yazara ait olduğu ve bu çalışmanın herhangi başka bir akademik yayın ortamına değerlendirme için gönderilmemiş olduğu sorumlu yazar tarafından taahhüt edilmiştir.

\section{Authors' Biodata/Yazar Bilgileri}

Songül TÜMKAYA Çukurova Üniversitesi Eğitim Fakültesi Temel Eğitim Bölümü'nde profesör olarak görev yapmaktadır. İlgi alanları aile katılımı, tükenmişlik, kişilerarası problem çözme ve mizahtır. 
Songül Tümkaya is working as a professor at Çukurova University Faculty of Education, Department of Primary Education. Her research interests are family participation, burnout, interpersonal problem solving and humor.

Gürkan ÇETİN Harran Üniversitesi Eğitim Fakültesi Temel Eğitim Bölümü'nde araştırma görevlisi olarak görev yapmaktadır. İlgi alanları ilkokulda fen eğitimi, metafor ve esnek öğrenme alanlarıdır.

Gürkan Çetin is working as a research assistant at Harran University Faculty of Education, Department of Primary Education. His research interests are science education in primary school, metaphor and flexible learning zones. 